greater complexity is the possibility of introducing new genetic material into germ cells with potential consequences for untold future generations.

While this book is an excellent stimulant to the giving of careful consideration to the use to which the rapidly proliferating knowledge in this area could and should be put, it is short on detailed discussion and argument about how to resolve the issues which its many authors recognize. However, as a timely reminder of the problems soon to come it does excellent service.

CHRISTOPHER HOWARD Senior Lecturer, Department of Psychiatry, Royal Free Hospital School of Medicine, Rowland Hill Street, London NW3 2PF

\section{Teaching and learning nursing ethics}

\author{
Edited by Ursula Gallagher and $\mathrm{K} M$ \\ Boyd, London, Scutari Press, 1991, \\ 84 pages, $£ 8.99$.
}

This is an extremely useful work. It centres upon the findings of a postal survey concerned with the teaching of nursing ethics undertaken by the Royal College of Nursing and the Institute of Medical Ethics. The survey was used as the basis of the work of a multidisciplinary working party whose task it was to examine the meaning of ethical issues for nursing and to consider what is involved in the teaching of ethics to nurses, midwives and health visitors. The survey involved 500 respondents from nursing education establishments.

The book opens with a chapter which sets the background in terms of the 'meaning of ethics' and the main ethical principles which are the concern of nursing ethics. The central chapters of the book present the information from the survey. The editors are to be complimented upon achieving an extremely high return rate for survey work -98 per cent. The survey included 147 centres of education, identified through the National Boards for Nursing, Midwifery and Health Visiting. The findings are summarised in a concise and helpful way in the form of a short paragraph or small table for each of the 17 questions. This allows the reader to come quickly to grips with the findings.
The remaining chapters contain the discussion and some of the working party's suggestions for nursing ethics teaching. Particularly interesting is the chapter on the reasons for teaching nursing ethics, especially the discussion of the question of whether teaching of ethics should run through all of the course or be flagged up as the ethics component.

In all, this is a useful book and, whilst it will be of particular interest to those coming for the first time to the question of how to teach nursing ethics, it should not be overlooked by the 'old hands' as it provides some insightful discussion. The survey provides us with a particularly succinct and clear account of the views of those charged with the task of teaching ethics to nurses, midwives and health visitors.

\section{Department of Nursing Studies, University of Edinburgh, Edinburgh}

\section{The uses of philosophy}

Mary Warnock, Oxford, Blackwell, 1992, 243 pages, £11.95.

This wide-ranging collection of essays originated in public lectures. Its themes include the source and scope of human duties; the relationship between private morality, law and public goods; children's rights; policymaking in the absence of moral consensus; honesty in public life; standard-setting in broadcasting and in general education; philosophy in the school curriculum; the aims of education; the place of moral instruction; religious imagination; the contribution of memory to the maintenance of personal continuity; the reality of inner experience and its relation to personal identity, and the greater integration of the elderly through acknowledgement of them as deliberative agents

The range is impressive. On many topics Baroness Warnock speaks with an authority born of her considerable experience both as a participant in public reflection on moral and social issues, and as an educator. She also writes as a professional philosopher conscious of the theoretical complexities of the problems she addresses. The latter aspect of her competence is to the fore in only two or three of the chapters (those on personal continuity

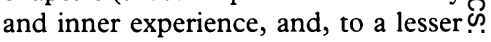
extent, that on religious imagination); but elsewhere she explicitly acknow- क् ledges philosophical difficulties, or writes in ways that signal her awareness of further complications.

It should be emphasised, however, that this is not a collection of $\frac{a}{\alpha}$ philosophical papers. Even where $\infty$ philosophical theory is operative, but $\overrightarrow{0}$ not dominant (as in the chapters mentioned), its touch is light. This is $\vec{\omega}$ no criticism. On the contrary, it is the very considerable merit of this book $\bar{\sigma}$ that it is not, and does not present itself as, exercises in 'applied philoso- 0 phy' of the sort now familiar. What we $N$ are offered are informed, thoughtful, $\vec{N}$ modest (but not bland or uncontroversial) essays on issues of the first $\rightarrow$ importance. Although these are not philosophical papers, they are essays that only a philosopher could have $\overparen{(})$ written, and they are a credit to the $\vec{\bullet}$ British tradition of clearly focused and carefully measured thinking.

Anyone setting about writing on a moral problem would benefit from reading Warnock's introduction, as would editors and publishers considering submissions in the field of $\frac{\mathrm{D}}{\mathrm{D}}$ philosophy and public policy. She charts something of the recent history $\overrightarrow{\overrightarrow{0}}$ of philosophers' involvement in 3 practical affairs and sets out what she takes to be the proper role of critical thinking. The methodology of analysing claims and identifying the assumptions, principles and attitudes 0 that underlie them, is adverted to and 3 . effectively implemented throughout the collection. Warnock's technique bears some relation to Rawls's methods in political philosophy. She works towards values and principles that animate our intuitive judgements, brings them into contact with problem cases and then moves to achieve some ${ }^{\text {or }}$ degree of consistency. In effect she is $\mathbf{O}$ saying: 'We favour this policy here because we have a deep commitment $\sigma$ to the following value; that being so we cannot deny the pull of this or that claim in these other cases'.

There are objections to this style of argument. It is open to charges of begging the question against other $\frac{\text { () }}{\mathbb{D}}$ standpoints, of being unduly con-@ servative of inherited principles, even $\stackrel{\varnothing}{\varrho}$ of being anti-philosophical. More toб the point, given that the issues are controversial, there is the question of the ownership and content of the intuitions being articulated. Warnockㅡㅡ. belongs within the tradition of liberal utilitarianism - though more to the 